\title{
Estimation of Genetic and Non-Genetic Parameters of Friesian Cattle under Hot Climate
}

\author{
Ihlam Ibrahim Eid \\ Ministry of Animal Resources and Fisheries, Khartoum, Sudan \\ E-mail: ihlameid@yahoo.com \\ Mohamed Omer Elsheikh \\ Department of Animal Genetics and Breeding, Faculty of Animal Production \\ University of Gezira, P.O.Box 20, Sudan \\ E-mail: mohamed1173536@yahoo.com \\ Ibrahim A/Salam Yousif \\ Department of Animal Genetics and Breeding, Faculty of Animal Production \\ Shambat, University of Khartoum., P.O.Box 32, Sudan
}

Received: September 13, 2011

doi:10.5539/jas.v4n4p95

\author{
Accepted: September 30, $2011 \quad$ Online Published: February 2, 2012 \\ URL: http://dx.doi.org/10.5539/jas.v4n4p95
}

\begin{abstract}
Data collected on purebred Friesian Heifers imported from Netherlands were used in this research to estimate genetic and non-genetic parameters. The average age at first calving (AFC), gestation period (GP), number services per conception (S/C), calving interval (CI), total milk yield (TMY), daily milk yield (DMY) and lactation length (LL) ranges were $24.9 \pm 2.34-26.50 \pm 2.84$ months, $274.21 \pm 55.57-273.3 \pm 4.03$ days, $3.92 \pm 2.77$ $-2.3 \pm 1.7,468.90 \pm 116.32-445.4 \pm 92.81$ days, $5533.14 \pm 1546.03-3748.2 \pm 1095.2 \mathrm{~kg}, 15.10 \pm 3.58-11.00 \pm 2.42 \mathrm{~kg}$, and $376.74 \pm 15.89-349.0 \pm 86$ days respectively.

Results showed that parity number had a significant $(\mathrm{p}<0.05)$ effect on $(\mathrm{S} / \mathrm{C})$. Also age at first calving had a significant $(\mathrm{p}<0.05)$ effect on milk yield per lactation and daily milk yield $(\mathrm{p}<0.01)$. Year of calving presented a significant $(\mathrm{p}<0.05)$ effect on DMY,S/C and $(\mathrm{CI})(\mathrm{p}<0.001)$. Whereas place of birth had a highly significant effect $(\mathrm{p}<0.001)$ on TMY and significant $(\mathrm{p}<0.01)$ effect on AFC.

Repeatability estimates for GP, S/C, CI, TMY, DMY and LL were found to be $0.170 \pm 0.045,0.090 \pm 0.044$, $0.361 \pm 0.047,0.420 \pm 0.061$ and $0.094 \pm 0.044$, respectively. While heritability estimates by paternal half-sib method ranged from $0.003 \pm 0.078$ for LL and $0.190 \pm 0.140$ for AFC. Whereas, estimates calculated by daughter-dam regression were found to be $0.710 \pm 0.456,0.320 \pm 0.168,0.106 \pm 0.120,0.100 \pm 0.150,0.174 \pm 0.136$ and $0,055 \pm 0.224$ for AFC, GP, S/C, TMY, DMY and LL, respectively.

Regarding phenotypic correlations among parameters, age at first calving was negatively correlated with other traits except for S/C and DMY. Whereas S/C exhibited positive phenotypic correlation with all the traits studied. Total milk yield was found to have positive correlation with DMY and LL. Concerning genetic correlations among traits were either inestimable or overestimated.
\end{abstract}

Keywords: Friesian, Hot climate, Genetic and non-genetic parameters

\section{Introduction}

In Sudan great interest for dairy cattle rearing has taken place by farmers and businessmen. This is because of the existence of inelastic market for milk all year round, in addition to the provision of the regular income for the producer resulting from fluid milk sale in the urban centers. The relatively poor potential of the local dairy cattle necessitates the importation of exotic high milk producing breeds in order to fill the gap between milk consumption and actual demand besides improving the genetic potential of the indigenous dairy breeds by crossing and selection. 
The maximum yield of these pure-bred cattle can hardly be attained under Sudan conditions because of the genotype $\mathrm{X}$ environment interaction. The adverse environmental conditions which include less adequate feed, prevalence of endemic diseases and harsh climatic conditions are the main predisposing factors that prohibit the standard production potential of the dairy sector in Sudan.

According to the different strategies suggested for filling the gap between milk demand and supply, the feasibility of importing pure exotic cattle to achieve this goal was strongly debatable among politicians and dairy breeders. Therefore the objectives of this study are:

- To assess the productive and reproductive pattern s of pure Friesian dairy cattle in Sudan.

- To estimate genetic parameters of the herd.

- To suggest plans for future development of the strategy for dairy farming in Khartoum state.

\section{Materials and Methods}

\subsection{Structure and Management}

The study was conducted at Dairy Land Farm about $35 \mathrm{~km}$ south of Khartoum city (17 $35^{\prime} \mathrm{N} 32^{\circ} 32^{\prime} \mathrm{E}$,). The herd was established in 1989 by importing Friesian heifers from Netherlands. Open housing system was the base in this farm, water was provided by automatic drinkers. The animals were kept in pens. Calves were grouped according to age or live body weight. Adult cows were divided into lactating, late pregnant and dry according to their physiological status. Feed requirement was determined according to milk yield and or body weight. Both natural and artificial mating systems were used in the farm. Well- fed heifers were considered to reach sexual maturity after their live weight becomes $370 \mathrm{~kg}$ that is attained normally on 16 months of age.

\subsection{Recording System}

The types of records available in the farm included: feeding, reproductive, milk yield, and herd structure records. Data obtained were classified according to seasons which included (autumn, winter and summer). Data were also grouped according to place of birth into two groups, namely imported and homebred.

\subsection{Statistical Analysis}

The data were analyzed using GLM of SAS (1988) to obtain the analysis of variance, and DMRT was used to test for significant differences. Genetic parameters estimates were conducted by Harvey's (1990).

The analysis of variance for the traits was performed by the following model:

Where:

$$
\mathrm{Y} i \mathrm{jkmn}=\mu+\mathrm{Aj}+\mathrm{Sj}+\mathrm{Pk}+\mathrm{Bm}+\mathrm{e}_{\mathrm{ijkmn}}
$$

Yijkmn $=$ the $\mathrm{n}^{\text {th }}$ observation on cow calved first at the age in the $\mathrm{j}^{\text {th }}$ season within $\mathrm{k}^{\text {th }}$ period at $\mathrm{m}^{\text {th }}$ place of birth, $\mu=$ the overall mean, $\mathrm{Aj}=$ the effect of the $\mathrm{i}^{\text {th }}$ age at first calving group $(\mathrm{i}=2,3$ and 3$), \mathrm{Sj}=$ the effect of the $\mathrm{j}^{\text {th }}$ season of calving $(\mathrm{j}=1,2$ and 3$), \mathrm{Pk}=$ the effect of the $\mathrm{k}^{\text {th }}$ period of calving $(\mathrm{k}=1,2$ and 3$), \mathrm{Bm}=$ the effect of the $\mathrm{m}^{\text {th }}$ place of birth $(\mathrm{m}=1$ and 2$), \mathrm{e}_{\mathrm{ijkmn}}=$ the random error.

The following model was used to show the effect of place of birth on age at first calving:

Where:

$$
\text { Yij }=\mu+B_{i}+e_{i j}
$$

Yij $=$ the $j^{\text {th }}$ observation for cow birthed at the $i^{\text {th }}$ place, $\mu=$ the overall mean., $B_{i}=$ the effect of $i^{\text {th }}$ place of birth ( $i$ $=1$ and 2 ), $\mathrm{e}_{\mathrm{ij}}=$ the random error.

Repeatability for the traits studied were estimated by intra-cow correlation by the following equation described by Becker (1984)

$$
\mathrm{R}=\sigma^{2} \mathrm{~b} / \sigma^{2} \mathrm{~b}+\sigma^{2} \mathrm{e}
$$

$\mathrm{R}=$ repeatability, $\sigma^{2} \mathrm{~b}=$ variance between cows, $\sigma^{2} \mathrm{e}=$ variance between records within cows.

\section{Results and Discussion}

\subsection{Non Genetic Parameters}

\subsubsection{Age at First Calving}

The average age at first calving (AFC) for the imported and homebred Friesian heifers were found to be $24.91 \pm 2.51$ and $26.50 \pm 2.84$ months respectively with coefficients of variation of $9.75 \%$ and $10.71 \%$. (Table 1 ). This is similar to the findings of Ibrahim (1989) for Friesian cattle in Sudan. However it is lower than $39.2 \pm 7.5$ that obtained by Tadesse et al (2010) in Ethiopia and $987.87 \pm 9.81$ days and that stated by Sattar et al (2005) in 
Pakistan for the same breed. The age at which the imported heifers commenced calving was significantly $(\mathrm{p}<$ 0.01 ) less than that of homebred heifers. Table 2 . This may indicate that sufficient feeding in the early life of the cows is important to obtain normal growth in relation to their age ( 2 years).

\subsubsection{Calving Interval}

The average calving interval (CI) was $468.90 \pm 116.32$ and $445.40 \pm 92.81$ days for imported and homebred Friesian cattle, respectively. This result agreed with Tahir and Maarof (1990) ones in Iraq and seemed to be

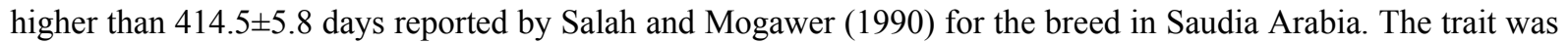
significantly $(\mathrm{p}<1.001)$ affected by year of calving and parity number. But season of calving did not significantly $(p<0.05)$ affect this trait. Table 2. Tahir and Maarof (1990) also reported significant effect of period of calving on the trait. . Fadlel Moula (1994) reported significant effect of parity number for Friesian crossbred, while Mbap and Ngere (1989) reported that this trait was insignificantly affected by parity number as well as season of calving. Also Mohamed Khair et al (2007) reported a high significant $(p<0.001)$ effect of parity on CI for Friesian crossbred in Sudan.

\subsubsection{Gestation Period}

Gestation Period (GP) was found to be $274.21 \pm 15.57$ and $273.30 \pm 4.03$ days for imported and locally born Friesian cows, respectively. Table 1. This result is in line with that obtained by Seida and Sayed (1990) in Egypt . While Osei et al (1991) reported slightly higher results. On the other hand Gwaza et al. (2007) reported $270 \pm 5.72$ days in Cameroon. However, all values were considered to be fallen with the accepted range of the breed. Year of calving, Parity and season of calving were found to have no significant effect on pregnancy duration (Table 2). Similar results of the effect of year of calving were expressed by Younis et al. (1976) for the same breed in Kuwait. However Sang et al. (1986) found that year of calving had significant influence on gestation period. Rafique et al. (2000) reported non-significant influence of parity number on this trait. On the other hand, Sang et al. (1986) found a significant effect of season of calving on pregnancy duration. The non significant effect of the year of calving, parity and season of calving on the trait may be attributed to the fact that this trait has almost a constant period during the life cycle of the cow.

\subsubsection{Services per Conception}

The average S/C was found to be $3.92 \pm 2.77$ and $2.3 \pm 1.70$ for imported and homebred, respectively Table 1 . This value is higher than 2.0 reported for Friesian dairy cattle in Nigeria by Ngodigha et al (2009) and 2.11 for Friesian in Pakistan (Niazi and Aleem 2003). While it is lower than the findings of Gyawu et al (1990) in Ghana and $3.07 \pm 0.10$ which is reported by Sattar et al (2005) in Pakistan. These differences might be due to variations in the management, environment and fertility status of the breeding cows. This trait displayed a significant $(\mathrm{p}<0.05)$ variation with respect to the year of calving and parity number Table 2 . This result is in line with that stated by Mangurkar et al (1986). While Tadesse et al. (2010) reported non-significant effect of parity number on the trait for Friesian cattle in Ethiopia. Season of calving have no significant $(\mathrm{p}<0.05)$ effect on the trait, this agreed with Njubi et al (1992) and disagreed with Juma and Al-Samarai. (1987).

\subsubsection{Total Milk Yield}

In the present study the mean TMY for imported and homebred cows were 5533.14 \pm 1546.03 and $3784.20 \pm 1095.2$ $\mathrm{kg}$ respectively. Table 1 . The later result is in line with $3710 \mathrm{~kg}$ that obtained by Tadesse et al (2010) for Friesian in Ethiopia but less than $5905 \mathrm{~kg}$ that found by Ajili et al (2007) in Tunis, $4489 \mathrm{~kg} / \mathrm{cow}$ in southern Malawi by Wollny et al (1998) and that reported by Ahmed et al (1997) in Libya. On the other hand it was more than that stated by Mbap and Ngere (1989) and Davinder and Jai (1983). (DMY) obtained in this study was $15.10 \pm 3.58$ and $11.00 \pm 2.42 \mathrm{~kg}$ for imported and locally born Friesian cows, respectively. This amount was more than that reported by Morsy et al. (1990) while it is less than the findings of Gwaza et al (2007) in Cameroon, Ahmed et al (1997) in Libya and Petrovic (1992) in Yugoslavia. This shows that there are great variations in milk yield for Friesian cattle in different places. This could be attributed to variation in managerial practices such as nutrition, disease control in addition to the effect of climatic conditions.

Parity number had a significant effect $(\mathrm{p}<0.001)$ on milk yield per day and non-significant effect on total lactation milk yield. A significant influence on DMY was also reported by Mbap and Ngere (1989) and Mohamed Khair et al (2007) that reported a significant effect on TMY also, while non-significant effect was stated by Amasaib et al (2008) for Friesian crossbred in India. The result of this study exerted that milk yield increased with the increase in parity, to attain a peak value at third lactation and started to decline thereafter. These results were in consistency with those suggested by Sattar et al (2005), Mbap and Ngere (1989) and Morsi (1986). 
The non significant effect of season of calving in TMY and DMY in this study was also confirmed by Subandriy et al (1986) and El-Amin et al (1986). Whereas Siqueria et al (1984) reported significant effect of season of calving on TMY. El-Amin et al (1986) reported that the highest milk production was produced by cows that calved in autumn but in the present study the highest milk production was recorded by cows that calved in winter and the lowest by summer. The place of birth had a significant $(p<0.001)$ influence on milk production. Foundation cows significantly produced more milk compared to those born in the herd, this finding agreed with Njubi et al (1992). This could be due to the differences in environmental conditions between countries of origin and tropical countries.

\subsubsection{Lactation Length}

The averages LL for imported and locally bred Friesian in this study were $376.74 \pm 150.89$ and $349.00 \pm 86.19$ days respectively. This length fell within the range reported by Skalicki and Latinovic (1990) and Juneja et al (1991) who recorded almost similar results (344 days) LL in Friesian cows in India. However a shorter means (291.86 \pm 6.55 days) was stated by Sattar et al (2005) and Alim (1986) in Libya. In this study LL is not significantly affected by year of calving, season of calving and parity number. The non significant effect of year of calving is agreed with Dhumal et al (1989) and disagreed with Karan and Joshi (1990). Njubi et al (1992) supported the non significant effect of parity on the trait, while Mohamed Khair et al (2007) found a significant effect in Friesian crossbred in Sudan. The results revealed that cows calved in winter lactated for longer period than those calved in other seasons. Whereas Nartey (1990) reported that cows calved in the rainy season had longer lactation length than those calved in dry season.

\subsection{Genetic Parameters Estimates}

Table 3 shows the estimates of genetic parameters e of traits studied. Heritability ( $h 2$ ) can't be estimated easily with great precision, and most estimates have rather large standard errors. Different estimates of the same character on the same organism show wide range of variation, some of which may reflect real differences between populations and /or the conditions under which they are studied (Falconer, 1982). The $\mathrm{h}^{2}$ estimate of AFC obtained by paternal half-sib correlation was found to be $0.190 \pm 0.140$. Table 3. High estimates for the same trait were reported by Khattab and Sultan (1993) and El-Amin et al (1986) for Friesian and Friesian crossbred in Sudan, respectively. While Moore et al (1990) reported lower estimate of $\mathrm{h}^{2}$ of AFC estimated by daughter-dam regression. $\mathrm{h}^{2}$ of GP estimated by paternal half-sib method was found to be $0.141 \pm 0.123$. Table 3 . This estimate fairly agreed with Moore et al (1990) whereas El-Amin et al (1986) reported a lower estimate for the same trait. $\mathrm{h}^{2}$ calculated by daughter-dam regression is higher than that obtained by El Amin (1969).

Heritability of TMY estimated by daughter-dam regression was within the range reported by Mosi (1988) for Friesian cattle in Kenya. Whereas Siqueria et al (1984) and Ali Hashemi et al (2009) found lower and higher estimates respectively. $\mathrm{h}^{2}$ for DMY estimated by paternal half-sib and daughter-dam regression were found to be $0.06 \pm 0.098$ and $0.0174 \pm 0.136$ respectively (Table 3 ). Both estimates were lower than that recorded by Arendonk et al (1987) for Dutch Friesian cows but less than $0.04 \pm 0.14$ that recorded by Gwaza et al (2007) for Friesian in Cameroon. $\mathrm{h}^{2}$ for LL was found to be $0.003 \pm 0.078$ using paternal half-sib correlation. This was lower than the findings of Skalicki and latinovic (1990) and Duarte (1983). In general the estimates of productive traits in this study were very low, so any effort to improve these traits by selection within the herd would be ineffective and the most useful way of improving these traits would be by improving management level.

Repeatability $\left(r^{2}\right)$ estimates for reproductive traits were relatively low. $\mathrm{r}^{2}$ estimates for GP is higher than the one obtained by El Amin et al (1986) and lower than that obtained by Sang et al (1986) for Holstein Friesian in Korea. On the other hand $\mathrm{r}^{2}$ estimates for $\mathrm{S} / \mathrm{C}$ is almost similar to the findings of El Amin et al (1986), but it is higher than that explained by Tong et al (1979) and lower than that reported by Raheja (1989). $\mathrm{r}^{2}$ for TMY and DMY were relatively medium and in consistent with the results of Chand and Narain (1986) but higher than the estimates of Alim (1986) and lower than the findings of Canon et al (1990). On the other hand $\mathrm{r}^{2}$ estimates for LL was found to be lower than that explained by El Itriby and Asker (1956). Falconer (1982) reported that the repeatability differs very much according to the nature of the character, and also of course, according to the genetic properties of the population and the environmental conditions under which the individuals are kept. In the present study the variation in repeatability estimates may be attributed to the differences in the records used in calculation of the values.

Regarding genetic and phenotypic correlations Table 4. AFC was negatively correlated with GP and positively with S/C, this findings is similar to the results of Moore et al. (1990) and Abubakar et al. (1986) who reported a negative phenotypic correlation between AFC and GP and between AFC and TMY. Whereas Barrada et al (1969) and El Barbary et al (1983) reported positive phenotypic correlation between AFC and TMY. In this study 
correlation between AFC and DMY was positive and low, this agreed with the result of Patro and Rao (1983). Also AFC was negatively correlated phenotypically with LL, this was disagreed with the result of Davinder and Jai (1983). TMY was positively correlated with all traits except AFC. Positive correlation with LL was also reported by Mohiuddin et al (1992), positive correlation with S/C was agreed with Vij and Tiwana (1986) who were also reported negative phenotypic correlation with GP and TMY. LL was negatively correlated with GP; this was disagreed with the findings of Abubakar et al (1986).

In this study, standard errors of genetic correlation were relatively high. This might be due to the effect of sampling since the number of records used was small due to the incomplete information reported in the records. Genetic correlation of GP with milk productive traits was found to be positive. Positive and high genetic correlation between GP and LL was also reported by Abubakar et al. (1987) and Pogacar (1982). The positive genetic correlation between traits indicates that if one trait is genetically improved, the other trait will also improve.

\section{Conclusions}

In hot climates raising crosses is far better than raising pure exotic cattle due to their better adaptation to the environment.

Because of the difficulties associated with pure exotic breeds requirement for high level of management, that might not be available in developing countries, therefore we suggest using cross breeding with indigenous as a suitable alternative. Moreover giving more care to feeding of calves in early life has a great impact on future performance.

\section{References}

Abubakar B Y, Mc Dowell R E \& vanVleck L D. (1986). Genetic evaluation of Holstein in columbia. Anim. Breed. Abst., 54, (10), 6415. J. Dairy Sci., 69 (4), 1081-1086. http://dx.doi.org/10.3168/jds.S0022-0302(86)80504-5

Abubakar, B Y, Mc Dowell, R E, Vleck, L D van \& Cabelloe, E. (1987). Phenotypic and genetic parameters for Holstein in Mexico. Anim. Breed. Abst., 55 (11), 6766. Tropical agriculture, Trindad (1987) 64 (1), 23-26.

Ahmed,M.K.A, Kharoofa, A.D S, Salhab, S A \& Zoied, A A. (1997). Comparative performance of imported and homebred Holstein Friesian cows. Almukhtar for science, (3), 9-21

Ajili N, Rekik A, Gara Ben \& Bouraoui R. (2007). Relationships among milk production, reproductive traits, and herd life for Tunisian Holstein-Friesian cows. African Journal of Agricultural Research, 2 (2), 047-051. http://www.academicjournals.org/ajar/PDF/Pdf2007/Feb/Ajili\%20et\%20al..pdf

Ali Hashemi, Iraj Bernousi, Sarain Razzagh Zadeh \& Mehdi Ranjbari. (2009). Estimates of Genetic Parameters of Productive Traits in Holstein-Native Crossbreds in W. Azarbaijan Province-Iran. Journal of Animal and Veterinary Advances, Year: 2009 Volume, 8 Issue, 5 P.917-919.

Alim K A. (1986). Aspects of animal production in Libya. World Rev. Anim. Prod., (21), 33-38.

Amasaib, E O, Abu Nikhaila, A M, Fadel Elseed, A N M.A \& Mohamed H E. (2008). Effect of Season of Calving and Parity on Some Productive Traits in Pure and Crossbred Cattle in Sudan. Research Journal of Dairy Sciences, 2 (1), 5-8, 2008.

Arendonk J A M, van Hoveni R \& De Boer W. (1987). Phenotypic and genetic association between fertility and production in dairy cows. Livestock Production Science, $21 \quad$ (1), 1-13. http://dx.doi.org/10.1016/0301-6226(89)90017-1

Barrada M S. Fahmy S K \& Abed El-Ghany W. (1969). Interrelationship between age at first calving and production during first lactation of imported Friesian cattle and their locally born daughter s. J. Anim. Prod. united Arab Republic, 9 (2),189-196.

Becker W A. (1984). Manual of procedures in quantitative genetics. $4^{\text {th }}$ edition Washington State University Pullman Washington.

Canon J Berge P J, Gutierrez J B \& Munoz A. (1990). Estimation of covariance components for milk and fat yield in the Spanish Holstein population using REML. Dairy sci. abst., 52, 7717.

Chand L \& Narain P. (1986). Lactation performance indices in dairy cattle. Anim. Breed. Abs., 54, 3635. Indian J. Dairy Sci., (1983) 36 (3), 325-326.

Davinder N A \& Jai S S. (1983). Factors affecting some of the economic traits in holstein Friesian cattle. Indian Vet. J., 60, 820-823. 
Dhumal M V, Sakhare P S \& Deshpande K S. (1989). Milk yield per day for lactation length and milk yield day of calving interval in Red Kandhari and crossbred cows. Indian J. Anim. Sci., 58 (10), 1217- 1220.

Duarte F A D E, Valle A \& Moure E. (1983). Production and genetic parameters of Holstein Friesian in a humid tropical climate in Brazil. Anim. Breed. Abst., 51 (1), 135.

El Amin F M, Simerl N A \& Wilcox C J. (1986). Genetics and environmental effects upon reproductive performance on Holstein crossbred in the Sudan. Anim. Breed. Abst., 54, 5101. J.

El Amin F M. (1969). Environmental and genetic factors influencing reproduction and milk yield of Sudanese indigenous dairy cattle. MSc. Thesis, university of Khartoum.

El Barbary A S A, Al Hakim M K \& Shalie A A A. (1983). Some economic characteristic of Friesian cattle in Iraq. Indian Vet. J., 60, 735-739.

El Itriby A A \& Asker A A. (1956). Repeatability of some dairy characters in cattle and Buffaloes in Egypt. Indian J. of Dairy Sci., (9), 157-163.

Fadlel Moula A A. (1994). Factors affecting reproductive and productive performance of crossbred dairy cattle in the Sudan. M.Sc. thesis University of Khartoum,Sudan.

Falconer D S. (1982). Introduction to quantitative genetics. Second edition. Longman scientific and technical press.

Gwaza D S, Okwori A I, Abu A H \& Fombah E M. (2007). A retrospective study on reproductive and dairy performance of Holstein Friesian on zero grazing in the western highland regions of Cameroon. Livestock Research for Rural Development, 19 (4) 2007 cited in http://www.lrrd.org/lrrd19/4/gwaz19057.htm

Gyawu P, Asara K \& Karikar P K. (1990). The performance of the imported Holstein Friesian and their progeny in the humid tropics. Dairy Sci. Abs., 52, 7733. Bulletin of animal health and production in Africa. (1988) 36 (4), 362-366.

Harvey W R. (1990). Mixed model least squares and maximum likelihood computer program.

Ibrahim M T. (1989). Study of milk composition and some production traits of Friesian and Sudanese grades dairy cattle. M.Sc. thesis. University of Khartoum.

Juma K H \& Al-Samarai, W W. (1987). Some economic traits of Iraqi buffaloes. J. Dairy characteristics. Anim. Breed. Abst., 55 (8), 5010. World review of animal production (1985)21 (4), 76-70.

Junejal J N Sastry S R \& Yadav B L. (1991). Performance of purebred herd of Jersey and Holstein-Friesian cows in the semi-arid region. Indian J. Anim. Prod. Management, 7, 240-241.

Karan P K \& Joshi B K. (1990). Factors affecting first lactation production and reproduction traits of karan swiss cattle. Indian J. Anim. Sci., 60 (2), 223-227.

Khattab A S \& Sultan Z A. (1993). Estimation of phenotypic and genetic parameters for first lactation performance in Friesian cattle in Egypt. Anim. Breed. Abst., 61 (1), 108. Egyptian J. Anim. Prod., (1993) 27 (2), 147-160.

Mangurkar B R, Gokhale S E, Shindey D N, Pande A B \& Bhadnis Y P. (1986). Reproductive performance of Holstein Friesian and Jersey purebred cow in a herdin india. Anim. Breed. Abst., 54(7), 4393. Indian J. Anim. Sci., (1985). 55 (10), 893-897.

Mbap S T \& Ngere L O. (1989). Productivity of Friesian cattle in a subtropical environment. Tropical Agriculture, (Trindad and Tobago). Apr. 66 (2), 121-124.

Mohamed Khair A A Ahmed, B T Lutfi M A \& Kurt J B. (2007). Milk production and reproduction traits of different grades of zebu $\mathrm{x}$ Friesian crossbreds under semi-arid conditions. Cited in http://arch-anim-breed.fbn-dummerstorf.de/pdf/2007/at07p240.pdf

Mohiuddin D, Ahmed Z, Khan M A, Akhtar P \& Ali S. (1992). Genetic, phenotypic and environmental correlations between milk yield and some other economic traits in Sahiwal cattle. Anim. Breed. Abst., 60 (11), 6829. Pakistan Vet. J., 11 (3), 113-116.

Moore R K, Kennedy B W, Schaeffer L R \& Moxley J E. (1990). Relationships between reproduction traits, age and body weight at calving and days dry in first lactation Ayrshires and Holstein. J.Dairy Sci., 73 (3), 835-841. http://dx.doi.org/10.3168/jds.S0022-0302(90)78737-1

Morsi M A, Najm A A, Sadek,R R \& El Rawy A. (1986). Some production characteristics of Friesian and Jersey cattle in Libya. Egyptian J.of Anim. Prod., 26(1), 15-34. 
Morsy M A, Nigm, A A, Sadek, R R \& El Rawy A. (1990). Some production characteristic of Friesian and Jersey cattle in Libya. Dairy sci. Abs. 52, 2188. Egyptian J. Anim. Prod., (1989) 26(1), 15-34.

Mosi R O. (1988). The use of milk records in cow evaluation and dairy cattle improvement in Kenya. Dairy Sci. Abst., 50 (9), 4771.

Nartey AT. (1990). Lactation performance of Friesian cattle on the Accra Plains. BSc dissertation, Department of Animal Science, University of Ghana, Legon, Ghana. 57pp. AGRIS Categories: animal husbandry.

Ngodigha E M, Etokeren E \& Mgbere. (2009). Evaluation of Age at First Calving and Number of Service per Conception Traits on Milk Yield Potentials of Holstein Frisian x Bunaji crossbred cows. Research Journal of Animal Science, 3(1), 6-9. http://docsdrive.com/pdfs/medwelljournals/rjnasci/2009/6-9.pdf

Niazi A A K \& Aleem M. (2003). Comparative Studies on the Reproductive Efficiency of Imported and Local Born Friesian Cows in Pakistan. Biological Sciences, 3 (4), 388-395. http://dx.doi.org/10.3923/jbs.2003.388.395

Njubi D J, Rege W, Thorpe E Collins-Lusweti \& Nyambaka R. (1992). Genetic and environmental variations in reproductive and lactational performance of the Jersey cattle in the coastal lowland semi-humid tropics. Tropical Anim. Hlth. Prod., 24, 231-241. http://dx.doi.org/10.1007/BF02356752

Osei S A, Effah K B \& Karkan P. (1991). The reproductive performance of Friesian cattle bred in the hot humid forest zones of Ghana. World animal review, 68, 52.

Patro B N \& Rao A S. (1983). genetic, phenotypic and environmental correlations between some production characters in the first two lactation of red Sindhi cattle. Indian J. Dairy Sci., 36, 107-110.

Petrovic M. (1992). The effect of sire on phenotypic parameters of lifetime dairy performance of Friesian cows. Anim. Breed. Abs., 60 (10), 6305. Stocarstvo. (1988) 42 (11/12), 429-440.

Pogacar T. (1982). Pregnancy duration of brown red and black pied cattle in Slovenia. Anim. Breed. Abst., 50 (12), 7146.

Rafique M, Chaudhry M Z \& Amer M A. (2000). Reproductive performance of inter se H. Friesian $\times$ Sahiwal crossbred. Pakistan vet. J., (20) 3.

Raheja K L, Bumside E B \& Schaeffer L R. (1989). Relationship between fertility and production in Holstein dairy cattle in different locations. J. Dairy Sci., 72, 2670-2678. http://dx.doi.org/10.3168/jds.S0022-0302(89)79408-X

Salah M S \& Mogawer H H. (1990). Reproductive Performance of Friesian Cows in Saudi Arabia I. Calving Interval, Gestation Length and Days Open. Journal of King Saud University. Agricultural Sciences, Volume 2, No 1. Cited in http://digital.library.ksu.edu.sa/paper1562.html

Sang B C, Cho Y Y \& Chee B C. (1986). Repeatability estimates of gestation length and birth weight and the environmental effects on these traits in dairy cattle. Anim.Breed Abs., 54, 6490. Korean J. Anim. Asc. (1986). 28 (4), 184-187.

SAS. (1988). SAS users guide. STATISTICS 1988 Ed. SAS Inc; Cary North Carolina.

Sattar A R H, Mirza A A K, Niazi \& Latif M. (2005). Productive and reproductive performance of Holstein Friesian cows in Pakistan. Pakistan Vet. J., 25(2), 75-81.

Seida A A \& Sayed M A. (1990). Gestation period and birth weight of purebred Friesian cattle in Egypt. AGRIS Abst., 1989-1990. AOAD.

Siqueria A C M F, Freitas M A R, Magalhaes L E D, Duarte F A M \& Lobo, R B. (1984). Heritability estimates and genetic correlation between milk and butter fat yield in Holstein cows. Anim. Breed. Abst., 52 (1-3), 294.

Skalicki Z \& Latinovic D. (1990). The influences of bull-sires on productive and reproductive traits, variation of cows in the black and white cattle population. Dairy Sci. Abst., 52, 4611.

Subandriy O, Sugiarti T \& Sitorus P. (1986). Productivity of imported and local Friesian dairy cattle in Pangalengan, Bandong, west Java. Anim. Breed. Abst., 54 (2), 7670. In the third world congress on genetic applied to livestock production, Lincoln, Nebraska, USA, July 16-22 (1986).

Tadesse M J, Thiengtham J, Pinyopummin A \& Prasanpanich S. (2010). Productive and reproductive performance of Holstein Friesian dairy cows in Ethiopia. Livestock Research for Rural Development, 22 (2) 2010 cited in http://www.lrrd.org/lrrd22/2/tade22034.htm

Tahir K N \& Maarof N N. (1990). Sudies on the performance of Friesian cattle in Iraq III. Service period and calving interval. Anim. Breed. Abst., 58(7), 4190. 
Tong A K W, Kennedy B W, Chicoine R L, Ror G L \& Moxley J E. (1979). Reproductive efficiency of artificially bred Holstein in Quebec. Anim. Breed. Abs., 48, 584. Canadian J. Anim. Sci., (1979) 59 (2), 419-425. http://dx.doi.org/10.4141/cjas79-052

Vij P K \& Tiwana M S. (1986). Phenotypic and Genetic Parameters of Some Production Traits in Buffaloes. Indian Vet. J., (63), 838-845.

Wollny C B A, Namwaza A G, Makamba T S W \& Küttner K. (1998). Zum Stand der Rinderzucht in Malawi. Archive fuer Tierzucht. Dummerstorf 41(1/2),33-44.

Younis A A, Abulnaga A, Kotby S \& Salman A A. (1976). A study of some reproductive traits in a Friesian herd kept under conditions. Indian J. of Anim. Sci., 46(11), 576-579.

Table 1. Means, Sd, CV of traits of the Imported and homebred Friesian Cows

\begin{tabular}{|l|l|l|l|l|l|l|}
\hline & \multicolumn{3}{|c|}{ Imported } & \multicolumn{3}{c|}{ Homebred } \\
\hline Trait & Mean & S.D. & C.V.\% & Mean & S.D. & C.V.\% \\
\hline AFC(months) & 24.91 & 2.43 & 9.75 & 26.50 & 2.84 & 10.71 \\
\hline GP (days) & 274.21 & 15.57 & 5.67 & 273.30 & 2.84 & 1.47 \\
\hline S/C & 3.92 & 2.77 & 70.66 & 2.30 & 1.70 & 73.91 \\
\hline CI (days) & 468.90 & 116.32 & 24.80 & 445.40 & 92.81 & 20.83 \\
\hline TMY $(\mathrm{kg})$ & 5533.14 & 1546.03 & 27.94 & 3784.2 & 1095.2 & 28.94 \\
\hline DMY $(\mathrm{kg})$ & 15.10 & 3.58 & 23.70 & 11.00 & 2.42 & 22.00 \\
\hline LL (days) & 376.74 & 150.89 & 40.05 & 349.00 & 86.19 & 24.69 \\
\hline
\end{tabular}

Table 2. Mean Squares of the factors affecting the measured traits

\begin{tabular}{|l|l|l|l|l|l|l|l|l|}
\hline Source of variation & df & TMY & LL & DMY & GP & S/C & CI & AFC \\
\hline Parity & 5 & 2310689.8 & 33287.38 & $49.72^{* * *}$ & 173.31 & $843.57^{*}$ & $62036.8^{* * *}$ & - \\
\hline AFC & 3 & $6951437.3 *$ & 6559.10 & $41.64^{* *}$ & 170.85 & 471.74 & 13820.79 & - \\
\hline Season of calving & 2 & 1617175.9 & 37838.97 & 25.38 & 158.02 & 532.51 & 18692.11 & - \\
\hline Year of calving & 2 & 1108123.6 & 18882.45 & $45.40^{*}$ & 115.08 & $1066.11^{*}$ & $95930.9 * * *$ & \\
\hline Place of birth & 1 & $93993720^{* * *}$ & 47747.77 & $330.53^{* * *}$ & 0.75 & 607.64 & 1014.09 & $55.93^{* *}$ \\
\hline
\end{tabular}

Table 3. Repeatability and Heritability estimates

\begin{tabular}{|l|l|l|l|}
\hline Trait & $\mathrm{r}^{2}$ & $\mathrm{~h}^{2} \mathrm{~A}$ & $\mathrm{~h}^{2} \mathrm{~B}$ \\
\hline AFC & - & $0.190 \pm 0.140$ & $0.710 \pm 0.456$ \\
\hline GP & $0.170 \pm 0.045$ & $0.141 \pm 0.123$ & $0.320 \pm 0.168$ \\
\hline S/C & $0.090 \pm 0.044$ & $\mathrm{NE}$ & $0.106 \pm 0.120$ \\
\hline CI & $0.121 \pm 0.044$ & $\mathrm{NE}$ & $\mathrm{NE}$ \\
\hline TMY & $0.361 \pm 0.047$ & $\mathrm{NE}$ & $0.100 \pm 0.150$ \\
\hline DMY & $0.420 \pm 0.061$ & $0.062 \pm 0.098$ & $0.177 \pm 0.136$ \\
\hline LL & $0.094 \pm 0.044$ & $0.003 \pm 0.078$ & $0.055 \pm 0.224$ \\
\hline
\end{tabular}

$\mathrm{NE}=$ Non-estimable., $\mathrm{h}^{2} \mathrm{~A}=$ Heritability estimated using paternal half-sib., $\mathrm{h}^{2} \mathrm{~B}=$ Heritability estimated using daughter-dam regression.

Table 4. Genetic and phenotypic correlations among traits

\begin{tabular}{|l|l|l|l|l|l|l|}
\hline Trait & AFC & GP & S/C & TMY & DMY & LL \\
\hline AFC & & & & & & \\
\hline GP & -0.047 & & & & $0.187 \pm 0.84$ & $0.53 \pm 0.71$ \\
\hline S/C & 0.130 & 0.101 & & & & \\
\hline TMY & -0.116 & 0.014 & 0.094 & & & \\
\hline DMY & 0.063 & 0.191 & 0.075 & 0.0325 & & \\
\hline LL & -0.075 & -0.068 & 0.009 & 0.480 & 0.362 & \\
\hline
\end{tabular}

*Genetic correlation above diagonal, phenotypic correlation below diagonal. 